\title{
Regulation of Leucine Transport and Binding Proteins in Escherichia coli
}

\author{
D. L. OXENDER AND S. C. QUAY \\ Department of Biological Chemistry, University of Michigan Medical \\ School, Ann Arbor, Michigan 48109
}

The branched-chain amino acids are transported into the bacteria Escherichia coli by two types of transport systems, a high affinity transport system (LIV-I) which requires periplasmic binding proteins and a low affinity membrane bound system (LIV-II). The LIV-I system is sensitive to osmotic shock while the LIV.II system can be observed in membrane vesicle preparations (Kaback, '71).

Berger and Heppel (74) have recently shown that the membrane bound transport systems such as the LIV-II system derive their energy from the "energy rich membrane state" while the shock-sensitive systems tend to utilize ATP more directly.

We have shown that high affinity leucine transport activity is highly regulated and responds to the level of leucine in the growth medium (Rahmanian et al., '73). The changes in transport activity closely correspond to similar changes in the levels of the leucine-binding proteins.

Table 1 shows the correlation between transport activity and the extractable level of the leucine-binding protein. There is a direct relationship between the level of leucine in the medium, the level of the leucine binding protein, and the level of the leucine transport systems (Penrose et al., '68). These results show that the level of binding protein determines the maximum transport capacity; therefore, the receptor site is the rate limiting component in the transport of leucine into $E$. coli.

Since this behavior was analogous to the regulation of leucine biosynthesis in $E$. coli, we explored the possibility that these two cellular processes were regulated in a concerted manner. For this project we collaborated with Dr. Umbarger of Purdue University who has extensively studied the biosynthesis of branched-chain amino acids (71). We provided mutants to Dr. Umbarger that were derepressed for leucine transport and he gave us several mu- tant strains that were derepressed for the biosynthetic enzymes. We examined the regulation of transport in these mutants. The results are shown in table 2 . The strains studied contained several mutations leading to derepressed leu $A B C D$, ilv $B$, and ilv $A D E$ activities as well as deletions of leu $A B C D$ and a promotor-operator $\mathrm{mu}$ tation of the leu operon. The transport levels as well as the leucine-binding activities in these strains were unaltered. When the ilv $B$ and the leu $B$ gene products were assayed in a strain which contains a fourfold derepression of branched-chain amino acid transport they were also found to be normal.

We concluded that the transport system and the biosynthetic enzymes for leucine, isoleucine and valine in $E$. coli are not regulated together by a cis-dominant mechanism and, although both systems appear to have components in common, they are at least partially separable (Quay et al., '75). In addition, we concluded that no portion of the leucine biosynthetic operon was necessary for branched-chain amino acid transport.

One obvious candidate for a common component in the regulation of both processes is the requirement for aminoacyltRNA rather than the free amino acid in repression. Extensive studies in several laboratories had already shown that some aminoacyl-tRNA synthetases are important both as components in protein synthesis and as a part of the regulatory system by which biosynthetic operons are repressed by their cognate amino acids (Brenchley and Williams, '75). The availability of temperature-sensitive mutants for the leucyltRNA synthetase provided an opportunity to determine if this enzyme was involved in the regulation of both transport and biosynthesis. A potential source of error in measuring transport in a prototrophic strain for leucine with a temperature-sen- 
TABLE 1

Repressibility of leucine binding protein and leucine transport ${ }^{1}$

\begin{tabular}{ccc}
\hline $\begin{array}{c}\text { Leucine in } \\
\text { growth medium }\end{array}$ & $\begin{array}{c}\text { Transport } \\
\text { capacity }\end{array}$ & $\begin{array}{c}\text { Leucine-binding } \\
\text { protein activity }\end{array}$ \\
\hline$m M$ & $\%$ & $\%$ \\
0.02 & 100 & 100 \\
0.04 & 83 & 78 \\
0.08 & 37 & 35 \\
0.16 & 30 & 27 \\
0.40 & 6 & 4 \\
\hline
\end{tabular}

1 E. coli K12 (ATCC 14948) was grown in glucose minimal salts plus leucine levels as indicated. Transport capacity and binding activity were assayed as indicated elsewhere (Oxender and Quay, '76)

sitive leucyl-tRNA synthetase is the large increase in the internal leucine level upon derepression of the biosynthetic operon that occurs at the non-permissive temperature. For these reasons we constructed a strain with a complete deletion of the leucine biosynthetic operon.

Cultures of strain EB144 containing the leucine deletion (ara-leu $\Delta$ 1101), and EB143 which contains the same deletion and the temperature-sensitive synthetase leu S1, were grown with $0.2 \mathrm{mM}$ leucine at the permissive temperature of $36^{\circ} \mathrm{C}$. Under these conditions the first order growth rate constant for both strains was $0.91 \mathrm{hr}^{-1}$. Table 3 contains data from these experiments. When the temperature of the cultures was shifted to $41^{\circ} \mathrm{C}$ the control strain EB144 gave a growth rate constant of $1.06 \mathrm{hr}^{-1}$ and the synthetase mutant stopped growing after about a $55 \%$ increase in cell mass. As shown in the table the transport activity for leucine, isoleucine and valine is greatly increased in the leu $S$ strain when it is grown at $41^{\circ} \mathrm{C}$. The growth temperature had little effect on either proline or histidine uptake. The presence of chloramphenicol (200 $\mathrm{mg}$ per liter) or rifampin (200 mg per liter) prevented the increase in branched-chain amino acid transport showing that the increased transport shown in the table represented synthesis of new transport components.

The first enzyme in the biosynthesis of isoleucine and valine is threonine deaminase (ilv $A$ gene product). The derepression of this enzyme which is shown in the table indicates the expected response of a isoleucine-valine biosynthetic enzyme which is subject to multivalent repression. The transport system, however, responds to only changes in the leucine level. When we examined the transport activity in mutants of isoleucine and valine tRNA synthetases we did not observe a derepression of transport activity under conditions where charging of isoleucine or valine to tRNA was defective.

Since the LIV-binding protein is required for and is rate limiting for transport of leucine the quantity of LIV-binding protein was examined in the shock fluid of strain EB143 and the leu S mutant EB144. For these studies the cells were grown in the

TABLE 2

Separation of leucine, isoleucine, and valine transport and biosynthesis ${ }^{1}$

\begin{tabular}{|c|c|c|c|c|}
\hline \multirow{2}{*}{ Strain } & \multirow[b]{2}{*}{ Phenotype } & \multicolumn{2}{|c|}{$\begin{array}{c}\text { Biosynthetic } \\
\text { enzymes }\end{array}$} & \multirow{2}{*}{$\begin{array}{l}\text { LIV } \\
\text { transport } \\
\text { system }\end{array}$} \\
\hline & & $i l v B$ & leuB & \\
\hline \multirow[t]{2}{*}{$\begin{array}{l}\text { CU5 } \\
\text { CU5002 }\end{array}$} & $\begin{array}{l}\text { wildtype } \\
\text { derepressed leu } A B C D\end{array}$ & 0.10 & 0.02 & 0.68 \\
\hline & ilv $B, i l v A D E$ & 0.44 & 0.21 & 0.81 \\
\hline \multirow{3}{*}{$\begin{array}{l}\text { ELK4 } \\
\text { LT2 } \\
\text { leu-500 }\end{array}$} & deletion of le $U O A B C D$ & 0.13 & $<0.003$ & 0.85 \\
\hline & $\begin{array}{l}\text { S. typhimurium; wildtype } \\
\text { S. typhimurium; down } \\
\text { promoter mutation of }\end{array}$ & - & - & 0.30 \\
\hline & the leu operon & 0.12 & $<0.003$ & 0.33 \\
\hline \multirow{3}{*}{$\begin{array}{l}\mathrm{EO} 300 \\
\mathrm{EO} 312\end{array}$} & wildtype & 0.085 & 0.019 & 0.66 \\
\hline & $\begin{array}{l}\text { Liv } R \text {; derepressed for } \\
\text { branched-chain amino } \\
\text { acid transport and }\end{array}$ & & & \\
\hline & binding protein & 0.067 & 0.014 & 2.14 \\
\hline
\end{tabular}

1 Results taken from cells grown in minimal glucose medium. Data on biosynthetic capacity are for $i l v B$ gene product, acetohydroxy acid synthetase and the leu B gene product, isopropyl malate dehydrogenase. The transport data came from uptake experiments at $1.5 \mu$ M leucine (Quay et al., '75). 
TABLE 3

Expression of transport and a biosynthetic enzyme activity in strains EB143 and EB144

\begin{tabular}{|c|c|c|c|c|c|}
\hline \multirow{2}{*}{ Strain } & \multirow{2}{*}{$\begin{array}{l}\text { Growth } \\
\text { conditions }\end{array}$} & \multicolumn{3}{|c|}{ Transport activities 2} & \multirow{2}{*}{$\begin{array}{l}\text { Threonine } \\
\text { deaminase }\end{array}$} \\
\hline & & Leu & Ile & Val & \\
\hline EB 143, ara-leusllol, leusl & $36^{\circ}$ & 100 & 65 & 87 & 26 \\
\hline EB144, ara-leu $\Delta l l o l$ & $36^{\circ}$ & 87 & 61 & 70 & 16 \\
\hline EB 143, ara-leusllol, leuSl & $41^{\circ}$ & 470 & 773 & 904 & 450 \\
\hline EB 144, ara-leu $\Delta$ llol & $41 \circ$ & 96 & 70 & 74 & 14 \\
\hline
\end{tabular}

1 Growth in glucose-basal salts medium plus $0.2 \mathrm{mM}$ L-leucine.

2 Transport was assayed at $1 \mu \mathrm{M}$ leucine (Leu) or isoleucine (Ile) and $3 \mu \mathrm{M}$ valine (Val). One hundred percent represents 0.23 mmol leucine taken up per min per $\mathrm{kg}$ cells dry weight.

3 Specific activity represents $\mu$ mol of $\alpha$-ketobutyrate formed per min/g of cellular protein. The growth media included $0.4 \mathrm{mM}$ L-leucine and L-isoleucine and $1 \mathrm{mM}$ L-valine.

TABLE 4

Branched-chain amino-acid binding proteins in strains EB143 and EB144

\begin{tabular}{|c|c|c|}
\hline Strain & $\begin{array}{c}\text { Growth } \\
\text { conditions } 1\end{array}$ & $\begin{array}{l}\text { Leucine } \\
\text { binding } \\
\text { activity } 2\end{array}$ \\
\hline 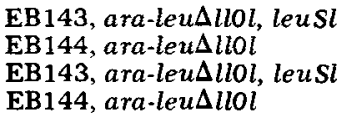 & $\begin{array}{l}36^{\circ} \\
36^{\circ} \\
41^{\circ} \\
41^{\circ}\end{array}$ & $\begin{array}{r}78 \\
100 \\
391 \\
85\end{array}$ \\
\hline
\end{tabular}

1 As in table 1 .

2 Proteins with leucine-binding activity were obtained by osmotic shock and were assayed at $10 \mu \mathrm{M}$ L-leucine and $4^{\circ}$ as described previously (Quay et al., '75). One hundred percent is equal to $0.46 \mu \mathrm{mol}$ of leucine bound per gram of protein.

same manner as described earlier for the transport studies. Table 4 shows the results. The parental strain EB143 remains repressed for the synthesis of the binding protein when the temperature is shifted from $36^{\circ}$ to $41^{\circ} \mathrm{C}$ while the leu $S$ strain EB144 shows a five-fold derepression in the synthesis of the binding protein. These results are consistent with a role of this protein in the rate limiting step in leucine transport and indicate that the synthesis of the binding protein is regulated by the internal level of activated leucyl tRNA or by the leucyl tRNA synthetase itself (Quay, Kline and Oxender, '75).

To distinguish between these latter two alternatives, a mutant with a defect in the maturation of leucyl-tRNA was used. The hisT locus in S. typhimurium codes for an enzyme which converts uridine to pseudouridine in tRNA for leucine, histidine and isoleucine. The regulation of histidine, isoleucine-valine and leucine biosynthetic enzymes in this mutation are altered in such a way that they are no longer sensitive to a limitation for their cognate amino acids (Cortese et al., '75). Figure 1 demonstrates that a limitation for leucine does not cause a derepression of the leu $B$ gene product, $\beta$-isopropyl malate dehydrogenase, in a leu $u^{-}$, his $T$ strain like it does in the isogenic $\mathrm{leu}^{-}$parent. Under the same growth conditions the transport activity of the leu ${ }^{-}$, his T strain also shows little sensitivity to the leucine level in the growth medium. These results can be taken as evidence that the repression of transport requires fully maturated tRNA which is amino acylated with leucine.

A number of recent reports (Bertrand et al., '75; Artz and Broach, '75; Roberts, '75) on regulation of operons in bacteria have proposed an "attenuator" type of regulation in which a site in the operator region acts as a "barrier" to transcription by RNA polymerase. At least one cellular factor, rho, has been implicated in this process (Crombrugghe et al., '73). In vitro transcription experiments have indicated that rho can catalyze transcriptional termination in a number of systems and more recent work indicates the $s u A$ locus, which is phenotypically characterized as a polarity suppressor (Ratner, '76), may be the structural gene for rho. To test if transport for leucine, isoleucine, and valine is under an attenuator-type mechanism, two strains which are leu- and isogenic for the suA locus were examined for their transport capacity. When grown in minimal glucose medium containing $0.4 \mathrm{mM}$ leucine the $s u A^{+}$wildtype had only $25 \%$ of the transport capacity of the suA strain, indicating the lack of a functional rho factor lead to a four-fold increase in transport capacity. In other systems the $s u A$ locus has led to as much as a ten-fold derepression (Wasmuth and Umbarger, '73). 


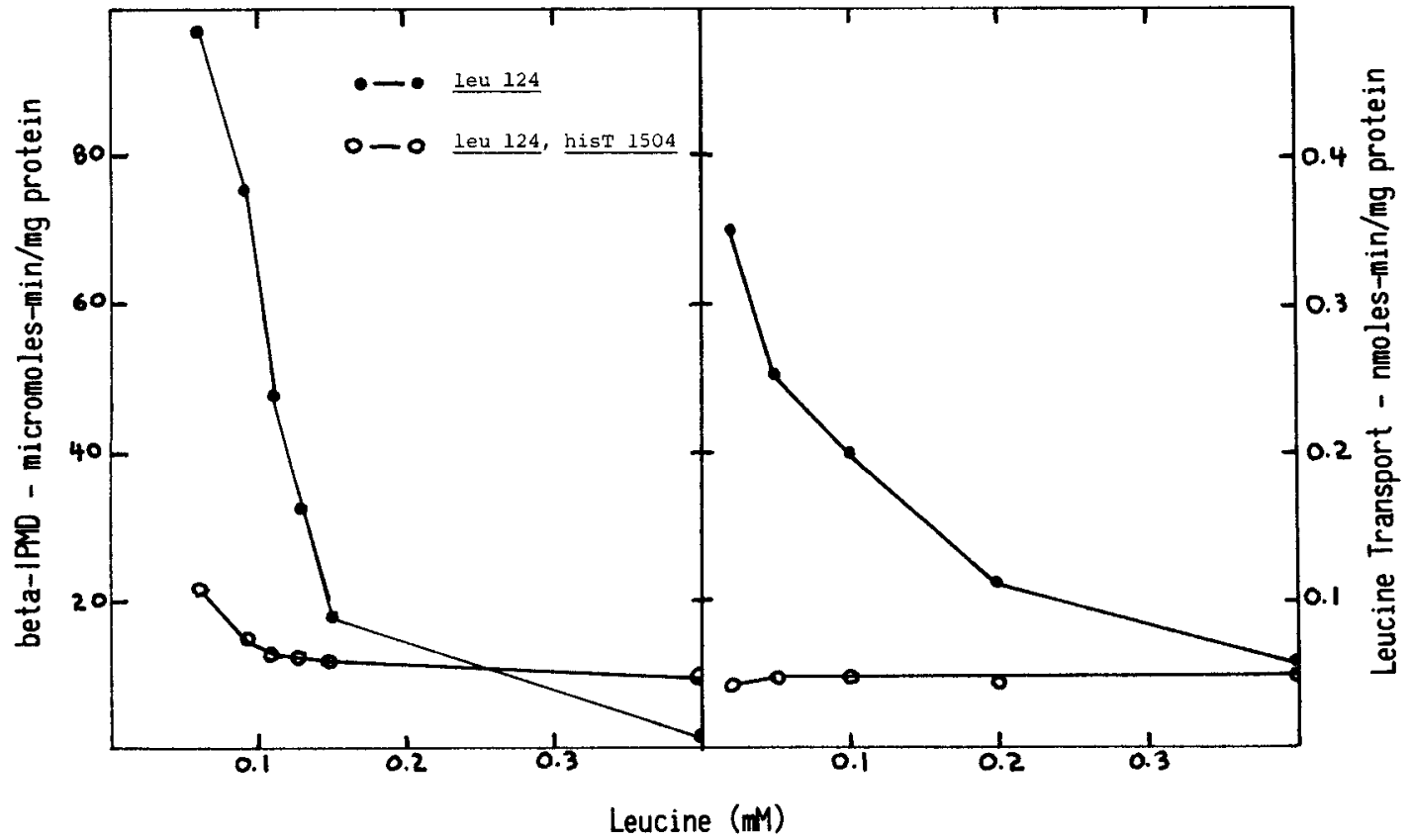

Fig. 1 The level of $\beta$-isopropyl malate dehydrogenase (left) and leucine transport (right) were determined as a function of the leucine level in growth media. Assays were performed as described elsewhere (Quay et al., '75).

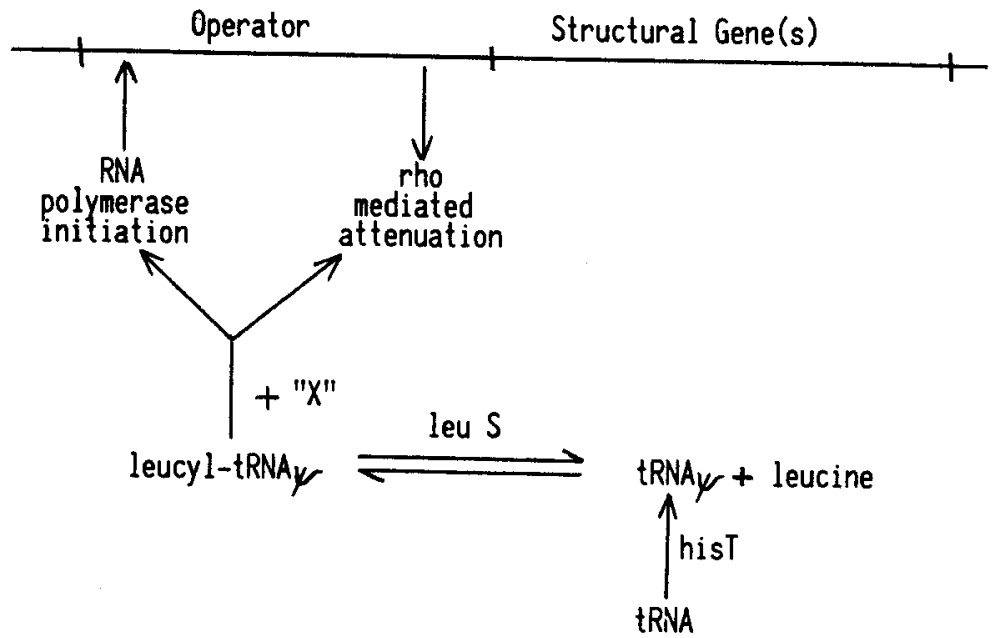

Fig. 2 Model of leucine transport regulation in E. coli.

In addition to concluding that some aspects of leucine transport regulation involve an attenuator site we now have the first direct evidence that regulation can occur at the level of transcription.

Figure 2 depicts the relationships among these various regulatory elements. One structural gene is depicted for didactic purposes only. Although we can conclude that tRNA ${ }^{\text {leu }}$ is involved in repression, we can not distinguish whether it acts as a negative effector when aminoacylated by the leucyl-tRNA synthetase or as a positive effector in the deacylated state. The his T 
locus defines an important step in the production of the corepressor. Transport regulation could be accomplished independent of the level of aminoacylation simply by regulating the degree of pseudouridination. The importance of the regulation at this level is not known. The nature of the aporepressor $\mathrm{X}$ is unknown at this time but could be the leucyl-tRNA synthetase, the leucine-binding protein, or some as yet unidentified protein. It is also not possible to determine which factors act at the level of initiation of RNA synthesis and which factors act by way of alterations in the rate of attenuation.

As can be seen, the complexity with which $E$. coli regulate the synthesis of membrane transport components parallels the regulation of other multiprotein functional complexes. We feel this system offers unique opportunities to study the genetics and molecular biology of membrane structure and function.

\section{ACKNOWLEDGMENTS}

The work performed in this laboratory was supported in part by Public Health Service Grant GM11024 to D. L. O. from the National Institute of General Medical Services.

\section{LITERATURE CITED}

Artz, S. W., and J. R. Broach 1975 Histidine regulation in Salmonella typhimurium: An activator-attenuator model of gene regulation. Proc. Natl. Acad. Sci. USA, 72: 3453.

Berger, E. A., and L. A. Heppel 1974 Different mechanisms of energy coupling for the shocksensitive and shock-resistant amino acid permeases of Escherichia coli. J. Biol. Chem., 249: 7747

Bertrand, K., L. Korn, F. Lee, T. Platt, C. L. Squires and $C$. Yanofsky 1975 New features of the regulation of the tryptophan operon. Science, $189: 22$.

Brenchley, J. E., and L. S. Williams 1975 Transfer RNA involvement in the regulation of enzyme synthesis. Ann. Rev. Microbiol., 29: 251.

Cortese, R., R. A. Landsberg, R. A. VonderHaar, H. E. Umbarger and B. N. Ames 1975 Pleiotropy of his T mutants blocked in pseudoridine synthesis in tRNA: Leucine and isoleucine-valine operons. Proc. Natl. Acad. Sci. USA, 71: 1857.

Crombrugghe, B. D., S. Adhya, M. Gottesman and I. Pastan 1973 Effect of rho on transcription of bacterial operons. Nature New Biology, 241: 260.

Kaback, H. R. 1971 Bacterial membranes. Methods Enzymol., 22: 99.

Oxender, D. L., and S. C. Quay 1976 Isolation and characterization of membrane binding proteins. In: Methods in Membrane Biology. E. D. Korn, ed. Plenum Press, New York, Volume 6, pp. 183-242.

Penrose, W. R., G. E. Nichoalds, J. R. Piperno and D. L. Oxender 1968 Purification and properties of a leucine-binding protein from Escherichia coli. J. Biol. Chem., 243: 5921.

Quay, S. C., E. L. Kline and D. L. Oxender 1975 Role of leucyl-tRNA synthetase in regulation of branched-chain amino acid transport. Proc. Natl. Acad. Sci. USA, $72: 3921$.

Quay, S. C., D. L. Oxender, S. Tsuyumu and H. E. Umbarger 1975 Separate regulation of transport and biosynthesis of leucine, isoleucine, and valine in bacteria. J. Bacteriol., 122: 994.

Rahmanian, M., D. R. Claus and D. L. Oxender 1973 Multiplicity of leucine transport systems in Escherichia coli K12. J. Bacteriol., 116: 1258.

Ratner, D. 1976 Evidence that mutations in the suA polarity suppressing gene directly affect termination factor rho. Nature, $259: 151$.

Roberts, J. 1975 Transcription termination and late control in phage lambda. Proc. Natl. Acad. Sci. USA, 72: 3300 .

Umbarger, H. E. 1971 The regulation of enzyme levels in the pathways to the branched-chain amino acids. In: Metabolic Pathways. H. J. Vogel, ed. Academic Press, New York, Volume 5, pp. $447-462$

Wasmuth, J. J., and H. E. Umbarger 1973 Effect of isoleucine, valine, or leucine starvation on the potential for formation of the branchedchain amino acid biosynthetic enzymes. J. Bacteriol., 116: 548. 